\title{
STUDI ANALISIS DAMPAK PEMASANGAN OVER LOAD SHEDDING TERHADAP PEMBEBANAN PADA SALURAN TRANSMISI 150KV DI BALI
}

\author{
M.A.Pradnya ${ }^{1}$, I.G.D.Arjana ${ }^{2}$, W.A.Wijaya ${ }^{3}$
}

\begin{abstract}
Safety system supply of electrical power to the transmission system is very important, to maintain the continuity of the load flow of electrical power. PT PLN (Persero) has continued to develop a security system, one with Over Load Shedding or OLS. Over Load Shedding is a form of action over load shedding that occurs automatically or manually installed on the transmission line as security in order to avoid or prevent the occurrence of total outages. This thesis is a case study occurred Cable Channels Over Load on Sea in Bali (January 2015), which reached 432MW from 340MW capacity may be burdened besides GI Gilimanuk and GI Pesanggaran Trip 125.4MW so OLS stage 1 and stage 2 works by removing loads of $89.76 \mathrm{MW}$. Load flow analysis results simulated using ETAP software Powerstation when OLS stage 1 work, the load flow into 359.532MW Submarine Cable Channels and when OLS stage 2 work, the load flow Submarine Cable Channels be 339.664MW, OLS worked for 9 seconds until the flow of electrical power loss can kontiyuitas met and the loadflow on the $150 \mathrm{kV}$ transmission system in Bali is maintained.
\end{abstract}

Intisari- Sistem pengaman suplai daya listrik pada sistem transmisi sangat penting, untuk menjaga kontinyuitas aliran daya listrik. PT.PLN (Persero) terus berupaya mengembangkan sistem pengaman, salah satunya dengan pelepasan beban lebih atau Over Load Shedding (OLS). Over Load Shedding merupakan suatu bentuk tindakan pelepasan beban lebih yang terjadi secara otomatis ataupun manual yang terpasang pada saluran transmisi sebagai pengamanan agar terhindar atau mencegah terjadinya padam total (Black Out). Studi kasus Skripsi ini terjadi Over Load pada Saluran Kabel Laut (SKLT) di Bali (Januari 2015) yang mencapai 432MW dari kapasitas yang boleh terbebani 340MW disamping GI Gilimanuk dan GI Pesanggaran Trip 125.4MW sehingga sistem relay OLS tahap 1 dan tahap 2 bekerja dengan melepas beban lebih sebesar $89.76 \mathrm{MW}$ pada GI Kapal dan GI Nusa Dua. Hasil analisa aliran daya dengan menggunakan simulasi software ETAP Powerstation saat OLS tahap 1 bekerja, aliran daya Saluran Kabel Laut menjadi 359.532MW dan saat OLS tahap 2 bekerja, aliran daya Saluran Kabel Laut menjadi 339.664MW, OLS bekerja selama 9 detik sampai aliran daya listrik yang hilang dapat terpenuhi dan kontiyuitas aliran daya pada Sistem Transmisi $150 \mathrm{kV}$ di Bali tetap terjaga.

Kata Kunci- Analisa Aliran daya (Load Flow Analisys), OLS (Over Load Shedding), ETAP Powerstation.

${ }^{I}$ Mahasiswa Teknik Elektro dan Komputer Fakultas Teknik Universitas Udayana, Kampus Bukit Jimbaran, BadungBali. 80361, Tel. 0361703315 fax. 0361703315; email iponk.henry@yahoo.co.id

${ }^{2,3}$ Dosen Teknik Elektro dan Komputer Fakultas Teknik Universitas Udayana, Kampus Bukit Jimbaran, BadungBali. 80361, Tel. 0361703315 fax. 0361703315; email dyanaarjana@unud.ac.id

\section{PENDAHULUAN}

Jaringan transmisi antar Gardu Induk sangat penting guna mendistribusikan daya listrik ke konsumen. Kondisi kelistrikan Bali saat ini, total beban permintaan (Demand) beban puncak pada tahun 2015 mencapai 807,6MW sedangkan Bali sendiri untuk memenuhi permintaan beban tersebut masih mengandalkan pembangkit utamanya yaitu (PLTG) Gilimanuk yang berkapasitas 130MW, (PLTG) Pemaron dan (PLTD) swasta Pemaron dengan kapasitas 88MW, kemudian dari (PLTD) Pesanggaran dan (PLTG)Minyak Pesanggaran yang berkapasitas 365MW, dan (PLTU) Celukan Bawang dengan kapasitas 380MW. Serta pasokan interkoneksi Jawa-Bali Saluran Kabel Laut yang berkapasitas 340MW.

Sistem transmisi tenaga listrik tentu saja akan mengalami berbagai gangguan. Gangguan yang terjadi pada saluran transmisi adalah gangguan tegangan lebih (Over Voltage) baik gangguan internal maupun gangguan eksternal, gangguan hubung singkat gangguan hubung singkat satu phasa ke tanah, dua phasa ke tanah, tiga phasa ke tanah, hubung singkat tiga phasa, hubung singkat dua phasa, gangguan daya balik (Reserve Power), gangguan beban lebih (Over Load). Gangguan-gangguan tersebut jika tidak di tanggulangi akan mengganggu aliran daya listrik ke konsumen. Berbagai cara dapat dilakukan untuk menjaga kontiyuitas aliran daya listrik dari gangguan yang terjadi pada sistem, salah satunya adalah pelepasan beban (Load Shedding)[1].

Terkait dengan Over Load Shedding atau pelepasan beban lebih beberapa penelitian telah dilakukan sebelumnnya. Pada penelitian yang berjudul "Studi Pengaruh Pemasangan Load Shedding Di Gardu Induk Pemecutan Kelod Dan Gardu Induk Nusa Dua Terhadap Kontiyuitas Aliran Daya Gardu Induk Nusa Dua" (Subakat Aris,2014). Dalam penelitian ini membahas tentang analisia setting arus, waktu serta koordinasi relay OCR (Over Current Relay) dan OLS (Over Load Shedding). Analisa setting relay dilakukan dengan analisa arus gangguan hubung singkat tiga phasa simetris menggunakan program ETAP Power Station. Dengan perhitungan manual di dapatkan nilai setting arus, waktu tunda dan waktu kerja relay OCR dan OLS tersebut. Selanjutnya hasil setting dan waktu kerja kedua relay tersebut akan dibangdingkan.

Penelitian berikutnya yang berjudul "Penerapan Relay Over Load Shedding Pada Trafo TD 3 \#30 MVA GI Sukamerindu Bengkulu Dengan Setting Arus Primier $70 \mathrm{kV}$ Untuk Mentripkan Penyulang $20 \mathrm{kV}$ " (Parahon Rubianto, 2013). Dalam penelitian ini membahas penyetelan arus setting dan waktu eksekusi skema pelepasan beban Over Load Sheeding ditentukan dengan mempertimbangkan beberapa hal 
seperti kemampuan penyaluran penghantar, koordinasi dengan OCR dan reclose.

Over Load Shedding bekerja sesuai tahapan yang ditentukan oleh PLN APB Bali. OLS pada sistem kelistrikan Bali terpasang pada kawat penghantar, yaitu pada jalur utama GI Gilimanuk - GI Negara - GI Antosari - GI Kapal - GI Pemaron dan line viber optic atau PLC sebagai kabel penghubungnya dan GI Kapal sebagai pusat terpasangnya sistem relay OLS karena pada GI Kapal bukan merupakan beban VIP atau beban yang diprioritaskan. Pemasangan OLS pada jalur utama disebabkan karena konduktor pada jalur ini tidak mampu lagi menopang beban yang ada di Bali, meningkatnya kebutuhan beban sedangkan kapasitas kabel belum di upratting, sehingga perlu dipasangnya sistem relay Over Load Shedding.

Studi kasus ini, terjadi gangguan pada sistem kelistrikan interkoneksi Jawa-Bali yang mengakibatkan kapasitas daya yang tidak terlayani sebesar $51.870 \mathrm{kWh}$ dengan beban padam 2809A, sehingga frekuensi sistem meningkat, governor pada GI Gilimanuk merespon turun beban dari 110MW menjadi 32MW disamping PLTG Pesanggaran Trip 35MW dan PLTD APEC 13MW, sehingga aliran daya pada kabel laut mencapai 432.08MW. jadi OLS yang bekerja adalah OLS di GI Kapal (Tahap 1) selama 4 detik dan OLS di GI Nusa Dua (Tahap 2) selama 4,5 detik [2].

\section{OVER LOAD SHEDDING}

Over Load Shedding merupakan suatu bentuk tindakan pelepasan beban lebih yang terjadi secara otomatis maupun manual untuk pengamanan operasi dari unit-unit pembangkit untuk menghindari atau mencegah terjadinya padam total (Black Out).

Apabila berkurangnya daya pembangkit berkisar $10 \%$ s.d $15 \%$, maka akan terjadi penurunan frekuensi karena governor pembangkit masih sempat bekerja dan daya cadangan panas yang ada (Spinning Reserve) sebesar 10\% s.d 15\% dapat digunakan dengan merubahnya menjadi daya listrik [3].

Pada perencanaan pelepasan beban dapat ditentukan terlebih dahulu beban-beban yang akan dilepaskan, dimana dibagi dalam dua kategori, yaitu [4] :

1. Beban Penting (Essential Load)

Beban-beban yang memegang peranan dalam proses suatu produksi dimana bila terjadi suatu gangguan dapat merusak atau mengurangi mutu dan hasil produksi tersebut.

2. Beban yang kurang penting (Non Essential Load).

Beban-beban yang tidak mempunyai pengaruh langsung terhadap proses pengolahan produksi.

Pelepasan beban lebih dapat dilakukan dengan dua cara, yaitu secara manual (manual load shedding) dan secara otomatis (Automatic Load Shedding) :

\section{Manual load shedding}

Pelepasan beban secara manual hanya digunakan dalam keadaan yang tidak begitu penting atau pada saat Control Load Shedding tidak bekerja sebagaimana mestinya (tidak dalam keadaan normal).

2. Automatic Load Shedding
Sistem pelepasan beban otomatis yang seringkali merupakan perpanjangan relay pengaman generator seperti Under Frequency Relay (UFR). Beban-beban yang akan dilepas harus ditentukan dahulu dan akan secara bertahap pada tiap-tiap frekuensi yang telah ditentukan. Masalah pokok dalam pelepasan beban disebuah sistem :

1) Besar beban yang akan dilepas pertingkat.

2) Menentukan jumlah tahapan pelepasan beban.

3) Kelambatan waktu yang direncanakan pada setiap waktu pelepasan.

4) Frekuensi dimana setiap tahapan dilepas

Salah satu contoh pengaplikasian sistem Over Load Shedding adalah untuk mengamankan suatu penghantar. Dimana OLS akan melepas beban secara otomatis pada suatu penghantar yang mengalami Over Load.

\section{A. Aliran Daya (Load Flow)}

Analisa aliran daya dilakukan untuk mendapatkan informasi mengenai aliran daya dan tegangan sistem tersebut. Informasi ini sangat dibutuhkan guna mengevaluasi kerja sistem tenaga dan menganalisa kondisi pembangkitan maupun pembebanan [5].

Untuk menentukan arus yang mengalir pada penghantar dapat menggunakan persamaan berikut [3] :

$$
\mathrm{P}=\sqrt{ } 3 \times \mathrm{V} \times \mathrm{I} \times \operatorname{Cos} \varphi
$$

dengan keterangan persamaan :

$$
\begin{aligned}
& \mathrm{P}: \text { Daya aktif yang mengalir } \\
& \mathrm{V}: \text { Tegangan } \\
& \mathrm{I}: \text { Arus }
\end{aligned}
$$

Beban sangat berpengaruh pada kualitas energi listrik dari sistem tenaga listrik. Bila beban tidak seimbang maka kualitas energi listrik mengalami perubahan, dalam keadaan steady state kualitas energi listrik ditentukan oleh [6] :

\section{Pemadaman}

Pemadaman akan membawa dampak berbeda terhadap jenis beban listrik. Bagi beberapa peralatan listrik pemadaman mampu merusak perangkat keras maupun lunak.

2. Turun dan Naik Tegangan

Penurunan atau kenaikan tegangan disebabkan oleh arus (I amper) yang melalui impedansi ( $\mathrm{Z}$ ohm). Perubahan tegangan sebesar ( $\mathrm{V}$ volt) diakibatkan adanya tahanan dan reaktansi dalam suatu rangkaian. Bila $\mathrm{V}=\mathrm{I}^{*} \mathrm{Z}$ maka perubahan tegangan pada $Z$ tetap terjadi perubahan besar arus akan mempengaruhi rugi-rugi daya komponen utama peralatan distribusi tersebut.

\section{B. Relay Pengaman}

Relay proteksi merupakan skema atau rangkaian yang mampu merespon terhadap adanya suatu gangguan atau kesalahan dalam sistem tenaga listrik dan secara otomatis memutuskan hubungan peralatan yang terganggu atau memberikan sinyal (alarm)[7].

Prinsip dasar relay pengaman umumnya dapat dibedakan menjadi tiga elemen fundamental seperti yang ditunjukan pada gambar $1[8]$ : 
1. Elemen perasa, mengukur adanya perubahan besaran listrik, misalnya perubahan arus atau tegangan pada sistem.

2. Elemen pembanding, berfungsi untuk membandingkan besaran yang terukur dengan besaran yang telah diset sebelumnya.

3. Elemen pengontrol, merupakan sinyal pengendali rangkaian lain, membuat sakelar suatu rangkaian tertutup.

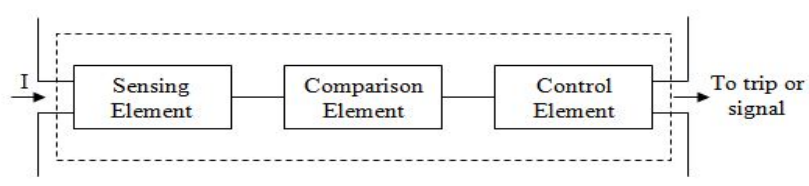

Gambar 1: Elemen Dasar Relay

Dalam rangkaian lsitrik terdiri dari tiga elemen, arus I adalah arus yang diserap rele dan sumber DC adalah sumber untuk rangkaian pen-trip. Besar arus ini dibatasi sampai harga tertentu, dan apabila melewati harga yang ditentukan maka jaringan akan diputus oleh CircuitBbreaker (CB) atau dikirim sinyal implus kepada alarm, atau menunjukan telah mengalir arus yang besar dalam rangkaian. Agar operasi rangkaian diatas berlangsung demikian, suatu peralatan khusus yang disebut relay harus dilibatkan dalam rangkaian.

\section{METODE}

Penelitian ini dilakukan di PT.PLN (Persero) Penyaluran dan Pusat Pengatur Beban Jawa Bali, Area Pelaksanaan Pemelihara (P3B JB APP) Bali Gardu Induk Kapal, Kabupaten Badung. Adapun alur analisis dapat dilihat pada gambar 2 .

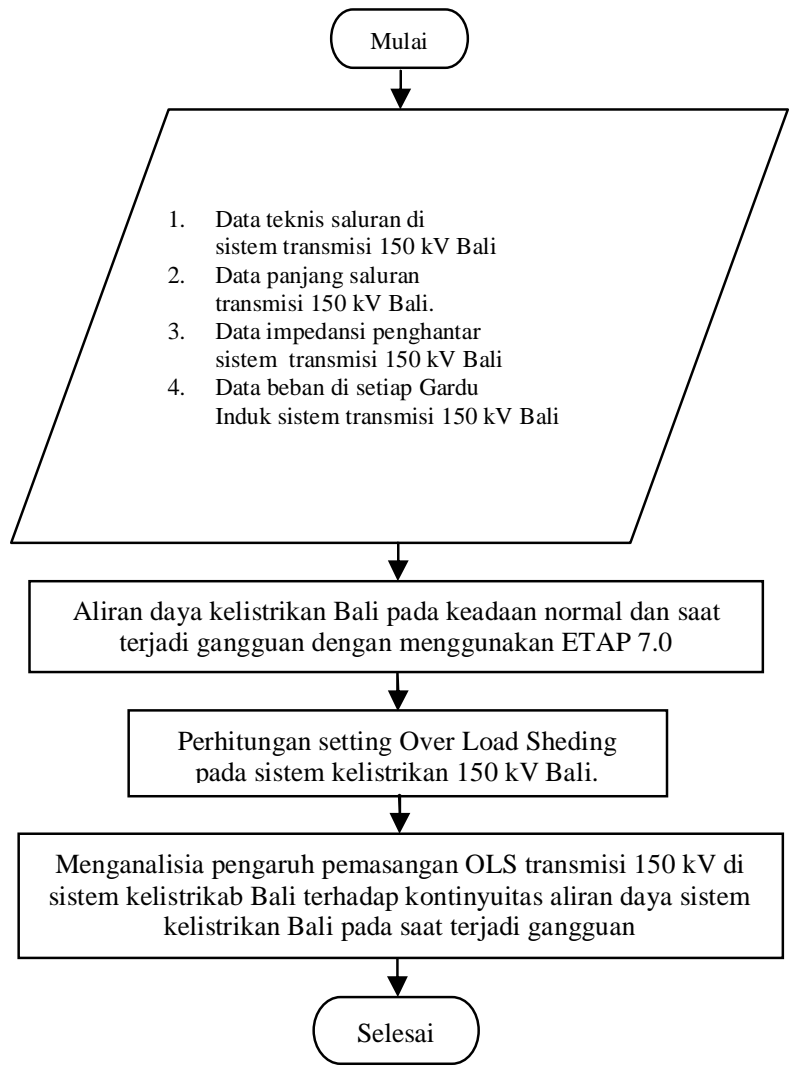

Gambar 2: Alur Analisis Skema Aliran Daya Over Load Shedding
Langkah analisa Over Load Shedding untuk mengetahui aliran daya pada Saluran Kabel Laut yang Over Load dengan Software ETAP PowerStation adalah sebagai berikut.

1. Jenis pengumpulan data-data (data teknis saluran, data penghatar, data impedansi, data trafo, dan data beban Gardu Induk)

2. Penggunaan Software ETAP PowerStation untuk mengetahui simulasi aliran daya saat OLS bekerja pada SKLT yang terjadi gangguan atau Over Load dengan membuat single line kelistrikan Bali pada ETAP, seperti pada gambar 3 .

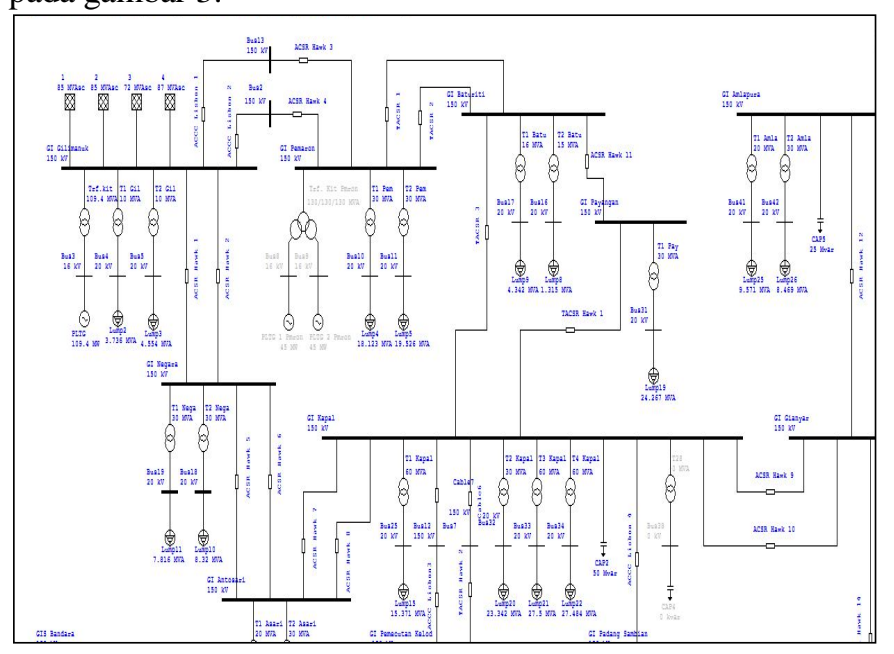

Gambar 3: Single Line Diagram pada ETAP

3. Memasukan data-data (data teknis saluran, data penghatar, data impedansi, data trafo, dan data beban Gardu Induk) di masing-masing bus. Seperti pada gambar 4.

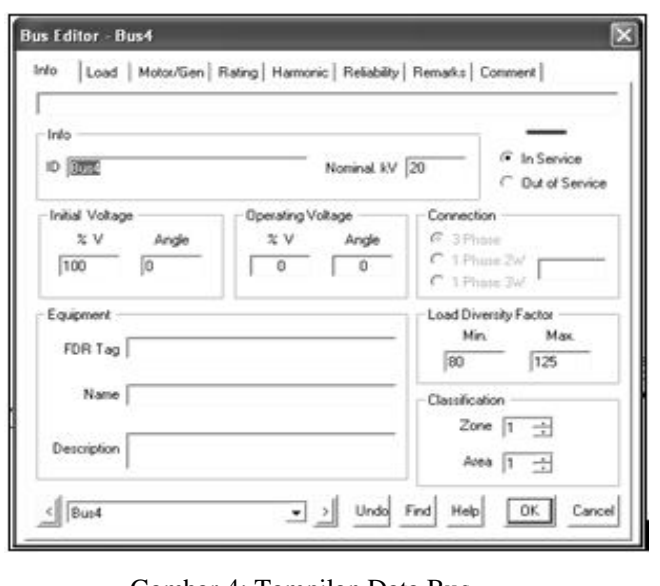

Gambar 4: Tampilan Data Bus

4. Hasil Load Flow Analisys dapat dilihat dengan me-running program pada toolbar ETAP dan membaca perbandingan hasil load flow pada SKLT yang terjadi Over Load. Simulasi pelepasan beban lebih atau OLS dibuat 4 kondisi, yaiut : Kondisi 1 saat keadaan normal, Kondisi 2 saat terjadi gangguan, Kondisi 3 saat OLS tahap 1, Kondisi 4 saat OLS tahap 2. Sampai kondisi SKLT kembali dalam keadaan nomal.

M.A.Pradnya: Analisa Pelepasan Beban Lebih.... 


\section{SIMULASI DAN PEMBAHASAN}

Studi kasus pada penelitian ini yang terjadi pada Saluran Kabel Laut terhubung ke Bali (Januari 2015) merupakan kejadian riil dimana SKLT mengalami gangguan menyebabkan frekuensi di Bali meningkat mencapai $51.47 \mathrm{~Hz}$, sehingga beban pada Saluran Kabel Laut mencapai 432MW/179.2Mvar/1922A [9], dari kapasitas SKLT yang boleh terbebani hanya 340MW. Pembangkit Gilimanuk merespon governornya turun beban ke 32MW di samping PLTG Pesanggaran Trip 35MW dan PLTD APEC Trip 13MW, mengakibatkan pembebanan pada SKLT mencapai 432MW.

Menggunakan Software ETAP PowerStation dapat dilakukan simulasi pelepasan beban lebih yang terjadi saat sistem relay OLS bekerja dan juga di dapat aliran daya yang mengalir pada Saluran Kabel Laut saat terjadi gangguan hingga kondisi penghantar kembali dalam keadaan normal.

Over Load Shedding yang bekerja adalah Tahap 1 dan 2 seperti yang terdapat pada tabel 1 dan 2, dimana OLS akan bekerja selama 4 detik pada tahap 1 dan 4,5 detik pada tahap 2. Jika tidak segera di tangani akan berdampak terjadinya pemadaman total (Black Out), disini perlu dilakukan pelepasan beban lebih atau Over Load Shedding untuk menjaga kontiyuitas aliran daya listrik.

Hasil dan pembahasan untuk analisa aliran daya pada SKLT Jawa-Bali yang terjadi Over Load adalah dengan menggunakan Software ETAP PowerStation.

\section{A. Skema Pelepasan OLS Tahap 1}

Pelepasan beban lebih berdasarkan target Trip tahap 1 terjadi di GI.Kapal yaitu pada Trafo 2 (21.73MW). Trafo 3 (26.14MW) dan Trafo 4 (3.77MW) beban pada trafo yang akan dilepas pada tahap 1 sebesar 51.64MW dengan asumsi waktu selama 4 detik, seperti pada tabel 1[1].

TABEL 1 : DATA TARGET TRIP OLS TAHAP 1

\begin{tabular}{|c|c|c|c|c|}
\hline No & Peralatan & $\begin{array}{l}\text { Gardu } \\
\text { Induk }\end{array}$ & $\begin{array}{l}\text { Beban } \\
\text { (MW) }\end{array}$ & Keterangan \\
\hline 1. & P.Tanah Lot & Kapal & 2.91 & Tahap 1 \\
\hline 2. & P.Blayu & Kapal & 1.98 & (4 detik) \\
\hline 3. & P.Penebel & Kapal & 2.72 & Inc_Trafo_2 \\
\hline 4. & P.Timpag & Kapal & 4.12 & \\
\hline 5. & P.Tibu Beneng & Kapal & 5.91 & \\
\hline 6. & P.Dalung & Kapal & 4.09 & \\
\hline 7. & P.BNR & Kapal & 1.37 & Inc_Trafo_3 \\
\hline 8. & P.Abianbase & Kapal & 6.23 & \\
\hline 9. & P.Peguyangan & Kapal & 3.77 & \\
\hline 10. & P.Sempidi & Kapal & 1.41 & \\
\hline 11. & P.Cokro & Kapal & 3.29 & \\
\hline 12. & P.Pidade & Kapal & 3.34 & \\
\hline 13. & P.Lumintang & Kapal & 3.45 & \\
\hline 14. & P.Poh Gading & Kapal & 1.25 & \\
\hline 15. & P.Exp STM & Kapal & 0.29 & \\
\hline 16. & P.Puspem & Kapal & 1.73 & \\
\hline 17. & P.Tangeb & Kapal & 3.77 & Inc_Trafo_4 \\
\hline \multicolumn{3}{|r|}{ Total } & 51.64 & \\
\hline
\end{tabular}

\section{B. Skema Pelepasan OLS Tahap 2}

Pelepasan beban lebih berdasarkan target Trip tahap 2 terjadi di GI.Pesanggaran yaitu pada Trafo 3 (14.67MW), Trafo 4 (7.09MW) dan Trafo 5 (7.25MW) juga terjadi pada GI.Nusa Dua yaitu pada Trafo 2 (2.33MW) dan Trafo 3 (6.77MW) beban pada tahap 2 yang akan dilepas sebesar 38.12MW selama 4,5 detik, seperti pada tabel 2[1].

TABEL 2 : DATA TARGET TRIP OLS TAHAP 2

\begin{tabular}{|c|l|l|c|c|}
\hline No & \multicolumn{1}{|c|}{ Peralatan } & $\begin{array}{c}\text { Gardu } \\
\text { Induk }\end{array}$ & $\begin{array}{c}\text { Beban } \\
\text { (MW) }\end{array}$ & Keterangan \\
\hline & Sanggaran T.3 & & & Tahap 2 \\
\hline 1 & P.Serangan & Sanggaran & 5.18 & $(4,5$ dtk) \\
\hline 2 & P.Sidakarya & Sanggaran & 6.04 & \\
\hline 3 & P.Pegok & Sanggaran & 3.45 & \\
\hline & Sanggaran T.4 & Sanggaran & & \\
\hline 4 & P.Palapa & Sanggaran & 2.30 & \\
\hline 5 & P.Pedungan & Sanggaran & 4.79 & \\
\hline & Sanggaran T.5 & Sanggaran & & \\
\hline 6 & P.Banteng & Sanggaran & 4.83 & \\
\hline 7 & P.Reagen & Sanggaran & 2.43 & \\
\hline & Nusa Dua_T.2 & & & \\
\hline 8 & P.Mumbul & Nusa Dua & 2.33 & \\
\hline 9 & P.Kampus & Nusa Dua & 3.00 & \\
\hline 10 & P.Kedonganan & Nusa Dua & 3.77 & \\
\hline & & & & \\
\hline
\end{tabular}

C. Simulasi Pelepasan Over Load Shedding

Simulasi pelepasan OLS yang terjadi pada Saluran Kabel Laut Jawa-Bali dengan menggunakan ETAP akan dilakuan dalam 4 simulasi.

1. Simulasi Aliran Daya dengan Software ETAP Powerstation Saat Keadaan Normal

Simulasi Analisa pelepasan beban lebih (Over Load Shedding) pada sistem transmisi $150 \mathrm{kV}$ di Bali dalam keadaan normal, dilakukan menggunakan ETAP dengan memasukan data impedansi, saluran kabel, kapasitas masing-masing Gardu Induk, dan penggunaan beban pada trafo. Seperti pada gambar 3 Single Line Diagram sistem kelistrikan Bali dan dengan memasukan data-data yang telah dikumpulkan, maka didapat hasil simulasi Load Flow pada ETAP saat kondisi kelistrikan aliran daya di Bali dalam keadaan normal seperti pada tabel 3 :

TABEL 3: HASIL RUNNING LOAD FLOW SISTEM KELISTRIKAN BALI SAAT KEADAAN NORMAL

\begin{tabular}{|c|c|c|c|c|}
\hline \multicolumn{4}{|c|}{$\begin{array}{l}\text { Filename: Study Case: LF } \\
\text { Alirandaya_SaatNormal } \\
\qquad \text { LOAD FLOW REPORT }\end{array}$} & $\begin{array}{c}\text { Page: } 1 \\
\text { Date: } 22 / 6 / 16\end{array}$ \\
\hline \multicolumn{2}{|c|}{ BUS } & \multicolumn{3}{|c|}{ LOAD FLOW } \\
\hline ID & $\mathrm{KV}$ & ID & MW & MVAR \\
\hline APB JATIM & 150 & GI Gilimanuk & 337.468 & -159.5 \\
\hline GI Gilimanuk & 150 & GI Negara & 199.847 & -68.164 \\
\hline GI Gilimanuk & 150 & GI Pemaron & 149.266 & -53.846 \\
\hline GI Pemaron & 150 & GI Baturiti & 108.854 & -77.805 \\
\hline
\end{tabular}


Dari tabel 3 didapat hasil running load flow pada Saluran Kabel Laut Jawa-Bali adalah sebesar 337.468MW dan masih dalam keadaan aman.

Berikut merupakan skema simulasi aliran daya saat keadaan normal.

\begin{tabular}{|c|l|l|l|}
\hline \multirow{2}{*}{ APB } & $($ OLS 560A $)$ & \multicolumn{2}{|c|}{ GI GILIMANUK } \\
\cline { 3 - 4 } JATIM & $337.468 \mathrm{MW}$ \\
\hline & KIT & $110 \mathrm{MW}$ \\
\hline Trafo & $8.0 \mathrm{MW}$ \\
\hline
\end{tabular}

Gambar 5: Skema Simulasi Aliran Daya Sistem Kelistrikan Bali Saat Keadaan Normal

Setelah dilakukan simulasi aliran daya pada sistem kelistrikan Bali maka didapat aliran daya yang mengalir pada Saluran Kabel Laut Jawa-Bali adalah sebesar 337.468MW, maka arus yang mengalir pada SKLT berdasarkan persamaan (1) adalah

Hasil aliran daya : 337.468MW-159.5Mvar

Arus yang di dapat :

$$
\begin{aligned}
\mathrm{P} & =\sqrt{ } 3 \times \mathrm{V} \times \mathrm{I} \times \operatorname{Cos} \varphi \\
337.468 & =1.732 \times 150 \times \mathrm{I} \times 0.85 \\
\mathrm{I} & =\frac{337.468}{1.732 \times 1500.85}=\frac{337.468}{220.83}=1.528 \mathrm{~A}
\end{aligned}
$$

Karena 4 penghantar maka :

$$
\mathrm{I}=\frac{1.528}{4}=382 \mathrm{~A}
$$

2. Simulasi Aliran Daya dengan Software ETAP Powerstation Saat Terjadi Gangguan

Meningkatnya frekuensi Saluran Kabel Laut yang mencapai $51.47 \mathrm{~Hz}$, sehingga beban pada SKLT mencapai 432MW/179.2Mvar/1922A dari kapasitas yang boleh terbebani hanya $340 \mathrm{MW}$, berikut merupakan data spesifikasi kapasitas penghantar pada saluran kabel laut [2] :

TABEL 4 : DATA SPESIFIKASI SALURAN KABEL LAUT

\begin{tabular}{|c|c|c|c|c|}
\hline $\begin{array}{c}\text { Pengha } \\
\text { ntar }\end{array}$ & $\begin{array}{c}\text { Jenis } \\
\text { Penghantar }\end{array}$ & $\begin{array}{c}\text { Panjang } \\
\text { Saluran } \\
(\text { KM) }\end{array}$ & $\begin{array}{c}\text { Daya } \\
\text { Terpasan } \\
\text { g (MW) }\end{array}$ & $\begin{array}{c}\text { Daya } \\
\text { Mampu } \\
\text { (MW) }\end{array}$ \\
\hline $\begin{array}{c}\text { SKLT } \\
1\end{array}$ & $\begin{array}{c}\text { OFC CU } \\
\text { PIRELI } \\
(3 \times 300 \\
\left.\text { mm }^{2}\right)\end{array}$ & 4,2 & 100 & 85 \\
\hline $\begin{array}{c}\text { SKLT } \\
2\end{array}$ & $\begin{array}{c}\text { OFC CU } \\
\text { PIRELI } \\
(3 \times 300 \\
\text { mm })^{2}\end{array}$ & 4,2 & 100 & 85 \\
\hline $\begin{array}{c}\text { SKLT } \\
3\end{array}$ & $\begin{array}{c}\text { OFC CU } \\
\text { PIRELI } \\
(3 \times 300 \\
\left.\text { mm }{ }^{2}\right)\end{array}$ & 6,5 & 100 & 85 \\
\hline SKLT & $\begin{array}{c}\text { OFC CU } \\
\text { PIRELI } \\
(3 \times 300 \\
\left.\text { mm }^{2}\right)\end{array}$ & 6,5 & 100 & 85 \\
\hline
\end{tabular}

M.A.Pradnya: Analisa Pelepasan Beban Lebih....
Disamping pembangkit Gilimanuk turun beban menjadi 32MW, PLTG Pesanggaran Trip 35MW dan PLTD APECTrip 13MW, sehingga total daya yang tidak tersalurkan saat terjadi gangguan adalah sebesar 125.4MW. Berikut merupakan hasil simulasi saat terjadi

\begin{tabular}{|c|c|c|c|c|}
\hline $\begin{array}{l}\text { Filename: } \\
\text { Alirandaya_S }\end{array}$ & $\begin{array}{r}\mathrm{LC} \\
\mathrm{Lan}\end{array}$ & $\begin{array}{c}\text { ETAP } \\
\text { 12.6.0H } \\
\text { Study Case: } \\
\text { uan } \\
\text { D FLOW RE }\end{array}$ & RT & $\begin{array}{l}\text { ge: } 2 \\
22 / 6 / 16\end{array}$ \\
\hline \multicolumn{2}{|c|}{ BUS } & \multicolumn{3}{|c|}{ LOAD FLOW } \\
\hline ID & KV & ID & MW & MVAR \\
\hline APB JATIM & 150 & GI Gilimanuk & 432.008 & -71.836 \\
\hline GI Gilimanuk & 150 & GI Negara & 216.516 & -50.689 \\
\hline GI Gilimanuk & 150 & GI Pemaron & 159.976 & -42.74 \\
\hline GI Pemaron & 150 & GI Baturiti & 119.992 & -67.76 \\
\hline
\end{tabular}
gangguan :

TABEL 5: HASIL RUNNING LOAD FLOW SISTEM KELISTRIKAN BALI SAAT TERJADI GANGGUAN

Dari tabel 5 didapat hasil running load flow pada Saluran Kabel Laut Jawa-Bali adalah sebesar 432.008MW saat terjadi gangguan.

Berikut merupakan skema simulasi aliran daya saat terjadi gangguan.

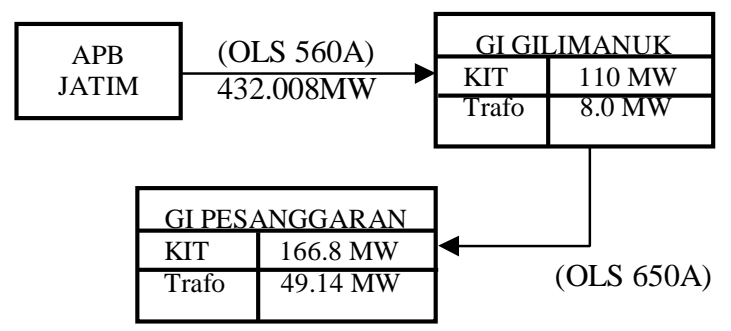

Gambar 6: Skema Simulasi Aliran Daya Sistem Kelistrikan Bali Saat Terjadi Gangguan

Pada skema simulasi aliran daya di atas dijelaskan bahwa terjadi penurunan daya pada GI.Gilimanuk dari 110MW menjadi 32MW daya yang hilang sebesar 77.4MW dan pada GI.Pesanggaran Trip dari 214.8MW menjadi $166.8 \mathrm{MW}$ daya yang hilang sebesar 48MW. Total daya yang hilang adalah sebesar 125.4MW. Maka arus yang mengalir pada SKLT berdasarkan persamaan (1) adalah

Hasil aliran daya $\quad$ :432.008MW-71.836Mvar

Arus yang di dapat :

$$
\mathrm{P}=\sqrt{ } 3 \times \mathrm{V} \times \mathrm{I} \times \operatorname{Cos} \varphi
$$

$432.008=1.732 \times 150 \times$ I $\times 0.85$

$$
I=\frac{432.008}{1.732 \times 1500.85} \frac{432.008}{220.83}=1.956 \mathrm{~A}
$$

Karena 4 penghantar maka :

$$
\mathrm{I}=\frac{1.956}{4}=489 \mathrm{~A}
$$


3. Simulasi Aliran Daya dengan Software ETAP Powerstation Saat Over Load Shedding Tahap 1 Bekerja

Over Load Shedding akan bekerja sesuai dengan target Trip atau tahapan-tahapan yang telah di tentukan, seperti yang dijelaskan pada tabel 1, OLS tahap 1 pada GI.Kapal akan melepas beban sebesar 51.64MW yang bekerja selama 4 detik. Berikut hasil load flow pada ETAP setelah OLS tahap 1 bekerja.

TABEL 6: HASIL RUNNING LOAD FLOW SISTEM KELISTRIKAN BALI SAAT OLS TAHAP 1

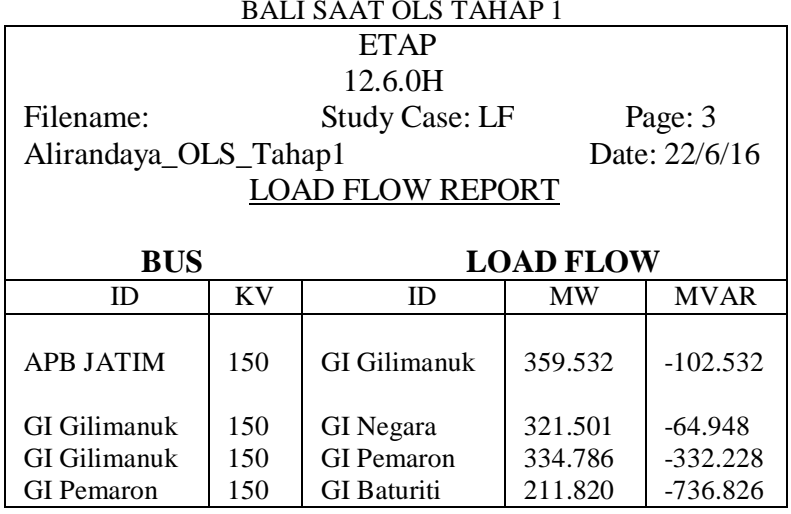

Dari tabel 6 didapat hasil running load flow pada Saluran Kabel Laut Jawa-Bali adalah sebesar 359.532MW saat OLS Tahap 1 bekerja.

Berikut merupakan skema simulasi aliran daya saat OLS Tahap 1 bekerja.

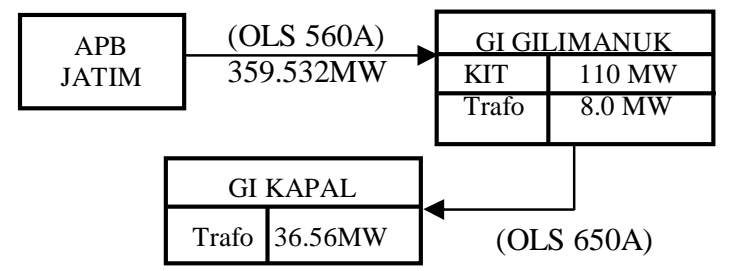

Gambar 7: Skema Simulasi Aliran Daya Sistem Kelistrikan Bali Saat OLS Tahap 1

Pada Tahap 1 OLS bekerja di GI.Kapal dengan melepas beban sebesar $51.64 \mathrm{MW}$, terjadi penurunan beban di GI.Kapal dari 88.2MW menjadi 36.56MW. Setelah OLS bekerja terjadi penurunan pada Saluran Kabel Laut Jawa-Bali dari 432.008MW menjadi $359.532 \mathrm{MW}$ tetapi pada penghantar masih mengalami Over Load sehingga OLS Tahap 2 harus bekerja. Maka arus yang mengalir pada SKLT berdasarkan persamaan (1) adalah

Hasil aliran daya $\quad: 359.532 \mathrm{MW}-102.532 \mathrm{Mvar}$

Arus yang di dapat :

$$
P=\sqrt{ } 3 \times \mathrm{V} \times \mathrm{I} \times \operatorname{Cos} \varphi
$$

$359.532=1.732 \times 150 \times$ I $\times 0.85$

$$
I=\frac{359.532}{1.732 \times 1500.85} \frac{539.532}{220.83}=1.628 \mathrm{~A}
$$

Karena 4 penghantar maka :

$$
\mathrm{I}=\frac{1.628}{4}=407 \mathrm{~A}
$$

4. Simulasi Aliran Daya dengan Software ETAP Powerstation Saat Over Load Shedding Tahap 2 Bekerja

Over Load Shedding tahap 2 bekerja setelah OLS tahap 1 bekerja selama 4 detik, pada tahap 2 juga bekerja sesuai dengan tahapan yang di jelaskan pada tabel 2 dan bekerja selama 4,5 detik. OLS tahap 2 bekerja pada GI.Pesanggaran dan GI.Nusa Dua dengan melepas beban sebesar 38.12MW. Berikut hasil load flow pada ETAP setelah OLS tahap 2 bekerja.

\begin{tabular}{|c|c|c|c|c|}
\hline $\begin{array}{l}\text { Filename: } \\
\text { Alirandaya_C }\end{array}$ & $\begin{array}{l}S \_T \\
\underline{L}\left(C_{0}\right.\end{array}$ & $\begin{array}{l}\text { ETAP } \\
12.6 .0 \mathrm{H} \\
\text { Study Case: } \\
\text { ap2 } \\
\text { D FLOW RE }\end{array}$ & RT & $\begin{array}{l}\text { ge: } 4 \\
22 / 6 / 16\end{array}$ \\
\hline \multicolumn{2}{|c|}{ BUS } & \multicolumn{3}{|c|}{ LOAD FLOW } \\
\hline ID & KV & ID & MW & MVAR \\
\hline APB JATIM & 150 & GI Gilimanuk & 339.664 & -124.02 \\
\hline GI Gilimanuk & 150 & GI Negara & 187.378 & -231.948 \\
\hline GI Gilimanuk & 150 & GI Pemaron & 141.208 & -112.228 \\
\hline GI Pemaron & 150 & GI Baturiti & 100.378 & -321.826 \\
\hline
\end{tabular}

TABEL 7: HASIL RUNNING LOAD FLOW SISTEM KELISTRIKAN BALI SAAT OLS TAHAP 2

Dari tabel 7 didapat hasil running load flow pada Saluran Kabel Laut Jawa-Bali adalah sebesar 339.664MW saat OLS Tahap 2 bekerja.

Berikut merupakan skema simulasi aliran daya saat OLS Tahap 2 bekerja.

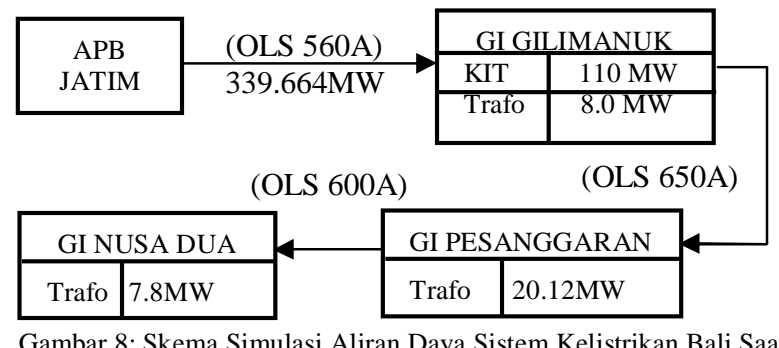

$$
\text { OLS Tahap } 2
$$

PadaTahap 2 OLS bekerja di GI.Pesanggaran dan GI.Nusa Dua dengan melepas beban sebesar 38.12MW, maka terjadi penurunan beban di GI.Pesanggaran dari 49.14MW menjadi 20.12MW dan pada GI.Nusa Dua dari 16.9MW menjadi 7.8MW. Sehingga aliran daya pada Saluran Kabel Laut Jawa-Bali yang Over Load dari 359.532MW menjadi 339.664MW. Aliran daya pada SKLT sudah dalam keadaan normal, sehingga OLS hanya bekerja sampai Tahap 2. Maka arus yang mengalir pada SKLT berdasarkan persamaan (1) adalah

Hasil aliran daya : 339.664MW-124.02Mvar

Arus yang di dapat :

$$
\begin{aligned}
\mathrm{P} & =\sqrt{ } 3 \times \mathrm{V} \times \mathrm{I} \times \operatorname{Cos} \varphi \\
339.664 & =1.732 \times 150 \times \mathrm{I} \times 0.85 \\
\mathrm{I} & =\frac{339.664}{1.732 \times 1500.85}
\end{aligned}
$$




$$
=\frac{339.664}{220.83}=1.538 \mathrm{~A}
$$

Karena 4 penghantar maka :

$$
\mathrm{I}=\frac{1.538}{4}=384.5 \mathrm{~A}
$$

TABEL 8 : HASIL ANALISA ALIRAN DAYA ( $L O A D F L O W)$ PADA SALURAN KABEL LAUT

\begin{tabular}{|c|l|r|r|r|}
\hline \multirow{2}{*}{ No. } & \multirow{2}{*}{$\begin{array}{c}\text { KONDISI } \\
\text { PENGHANTAR }\end{array}$} & \multicolumn{3}{|c|}{ LOAD FLOW } \\
\cline { 3 - 5 } & & \multicolumn{1}{|c|}{ MVAR } & \multicolumn{1}{|c|}{ AMP } \\
\hline 1. & Keadaan Normal & 337.468 & 159.5 & 382 \\
\hline 2. & Terjadi Gangguan & 432.008 & 71.836 & 489 \\
\hline 3. & OLS Tahap 1 & 359.532 & 102.532 & 407 \\
\hline 4. & OLS Tahap 2 & 339.664 & 124.02 & 384.5 \\
\hline
\end{tabular}

\section{KESIMPULAN}

Berdasarkan hasil analisa aliran daya (Load Flow) pada Saluran Kabel Laut yang dilakukan dengan menggunakan simulasi Software ETAP Powerstation, maka dapat disimpulkan.

1) Simulasi dilakukan berdasarkan Studi Kasus yang terjadi pada Saluran Kabel Laut yang menghubungkan Jawa-Bali (Januari 2015) dimana sistem relay OLS bekerja sesuai tahapan target yang telah di tentukan oleh APB PLN Bali yaitu pada tahap 1 di GI Kapal OLS melepas beban 51,64MW, tahap 2 di GI Nusa Dua dan GI Pesanggaran 38,12MW jadi total beban lebih yang di lepas adalah 89.76MW selama 9 detik sampai kondisi penghantar yang over load dalam keadaan aman,sistem relay Over Loaad Sheeding disini berfungsi menjaga kontiyuitas aliran daya listrik pada sistem transmisi $150 \mathrm{kV}$ di Bali.

2) Pemasangan relay OLS pada sistem kelistrikan Bali sangat membantu kerja APP PT.PLN Bali dalam menjaga kontiyuitas suplay daya dari PLN ke konsumen.

3) Perlu dilakukan upratting yang kontinyu terhadap konduktor pada jalur utama yaitu pada GI.Gilimanuk GI.Negara - GI.Antosari - GI,Kapal - GI.Pemaron, karena konduktor pada jalur ini sudah tidak mampu menopang beban lebih jika terjadi over load disalah satu penghantar.

\section{REFERENSI}

[1] PLN (Persero), PT. 2015. Logsheet APB Bali Bulan Januari 2015 : PT. PLN (Persero) Region Bali.

[2] PLN (Persero), PT. 2015. Logsheet APB Bali Bulan Nopember 2015 : PT. PLN (Persero) Region Bali.

[3] Subakat, A. 2014. "Studi Pengaruh Pemasangan Load Shedding di Gardu Induk Pemecutan Kelod dan Gardu Induk Nusa Dua". (tugas akhir). Jimbaran : Jurusan Teknik Elektro Universitas Udayana.

[4] Parahon. R. 2013. "Penerapan Relay Over Load Shedding pada Trafo TD 3 \#30MVA GI Sukamerindu Bengkulu Dengan Setting Arus Primier 70kV Untuk Mentripkan Penyulang 20kV'.

(tugas akhir). Semarang : Jurusan Teknik Elektro Universitas Diponegoro.

[5] Setiawan, N. Studi Aliran Daya Jaringan Distribusi $20 \mathrm{kV}$ di Bali Dengan Metode Yang Lebih Cepat. Majalah Ilmiah Teknologi Elektro Vol.6 No.1 Januari-Juni 2007

M.A.Pradnya: Analisa Pelepasan Beban Lebih....
[6] Weking, A.I. Pengembangan Analisis Aliran Daya Dengan Memperhitungkan Pengaruh Kualitas Energi Listrik. Majalah Ilmiah Teknologi Elektro Vol.8 No.1 Januari-Juni 2009

[7] Mardiana, A. 2016. "Rancang Bangun Penyeimbang Arus Beban Pada Sistem 3 Fasa Menggunakan Mikrokontroler AT Mega 2560". (tugas akhir). Jimbaran : Jurusan Teknik Elektro Universitas Udayana.

[8] Arismunandar, A. 2004. Teknik Tenaga Listrik (Jilid II). Jakarta : PT Pradnya Paramita.

[9] PLN (Persero), PT. 2015. Statistik PLN 2015 : PT PLN (Persero) P3BJB Region Jawa Timur dan Bali. 
\{Halaman ini sengaja dikosongkan\} 